\title{
ON THE BIBLICAL EXPRESSIONS FUNCTIONING IN THE MODERN SPANISH MEDIA DISCOURSE
}

\section{Anna Karpachova ${ }^{1}$ Liudmyla Shuppe ${ }^{2}$}

DOI: https://doi.org/10.30525/978-9934-588-11-2_41

The readership in the countries that have a long Christian history - such as Spain tend to easily recognize the biblical expressions in a text, therefore their use in the media can be pragmatically explained.

The Spanish literature traditionally distinguishes between the following types of media: the press, propaganda, commercial advertisements, and public relations information, the main goal of each is to form the addressees' certain opinion or state.

The Spanish mass media fall into three types of information data: pure information (news), editing data, and drafts, with each possessing their own style.

The Spanish media discourse analysis makes it possible to characterize it as highly pragmatical, which is particularly seen from the wide usage of marked vocabulary units.

In general, idioms are very pragmatically efficient by «ensuring emotivity and expressivity by means of figurative motivation. They are more efficient means of expressing emotivity than words, because idioms, reflecting the image of situation, build up a microtext within a text» $[1$, p. 41$]$.

Kunin O. points out the following functions of the phraseological units: nominative, stylistic (figurative-expressive, emotional-expressive, language concession function), cumulative (generalization of the nation's life experience, realized in speech as a piece of advice, warning), directive (educational), pragmatic (direct impact on an addressee, realized within a context), text-building (realization of the phraseological units linguistic peculiarities, which enables them to structure the text as its linking elements), and summarizing [2, p. 177].

A Spanish linguist Alberto Zuluaga distinguishes between the constant functions (funciones inherentes) of idioms (do not depend on the context) and variable functions (funciones no inherentes) [3, p. 634]. The researcher points out five constant functions: phraseological, distinctive, connotational, figurative, and poeticplayful. Phraseological function is characteristic of all phraseological units and consists in simplification of the message formation, as well as its reception and decoding, which makes communication more efficient.

Let us analyse a set of examples of the biblical expressions usage in the modern Spanish media discourse. The analysis includes the examples of non-occasional usage, but pragmatically conditioned: each of the biblical expression (as well as any other phraseological unit in general) possesses a neutral equivalent (descriptor - according to a glossary by Cherdantseva T.) that could substitute the former in the text:

${ }^{1}$ Odessa I.I. Mechnikov National University, Ukraine

2 Odessa I.I. Mechnikov National University, Ukraine 
En la guerra política que se ha levantado, el PP insiste en su papel de oposición y echa tierra sobre los gobiernos socialistas (Cambio 16) [4].

One of the Gospel scenes shows a madman following Jesus Christ and throwing dirt at him. The Spanish phrase echar tierra sobre / a uno definitely has negative connotation, because according to the biblical context such behaviour is characteristic of those who spread slander or persecute the men of God. The use of the biblical expression that arouses the reader's negative associations in relation to the party becomes explicit, considering the fact that the magazine favours the left powers.

The majority of media's policy obviously consists in following a certain formal objectivity in the information delivery, therefore the author's personal evaluation of that or other event or character is to be the more disguised, the more ambiguous attitude is shown towards them by society. But if society's consensus of opinion is firm, then the journalist can express their thoughts directly.

Thus, the following example includes a part of the paroemia referring the reader to an image of «a wolf in sheep's clothing», which doubtlessly has a negative connotation:

«Tened cuidado con los falsos profetas; vienen a vosotros disfrazados de ovejas, pero por dentro son lobos rapaces».

Es precisamente esa moderación estratégica la que ha llevado a PSOE y PP a referirse a Beiras como un candidato «que se ha vestido con la piel de cordero para engañar al electorado» (ABC) [5].

In addition to the biblical expression with a negative connotation there is an explicitly shown negative attitude to the nationalistic party representative who deceives his voters.

The majority of linguists divide the phraseological transformation into semantic (literalization, semantization, realization of semantic two-dimensional nature etc.) and structural (compression or substitution of components, prolongation of the idiom, reordering of components etc.) [6, p. 263].

Let us look at several types of the biblical expressions contextual transformations that include the most wide-spread forms of occasional transformations.

The biblical expression's constituents' substitution

In order to achieve a certain pragmatical goal the journalists sometimes expose biblical expressions to an «artistic» processing by substituting some original components to give the expression a new meaning, but preserving the original connotation at the same time:

En cuanto a eso de los hombres, pues qué quieres que te diga, un poquito sí que nos gusta crear falsas ilusiones, para estar en el candelero y porque no sólo de pan vive la mujer, aunque éste no parece el caso (Marie Claire, edición española) [7].

The idioms often remain unchanged, though the context behind them is aimed at the reader's positive feedback and smile, hence a tricky ending appears, disposing of the biblical expression's original meaning and its sacredness: "No solo de pan, afortunadamente, vive el hombre: también está la mortadela de aceitunas».

The biblical expression's constituents' prolongation or shortening 
The biblical expressions are often transformed by adding separate components. The idiom's structure is intentionally widened by the author, which results in its being more expressive, emotive, and figurative.

The article España: el PP o la nada (El País. 02.03.2014) in the Spanish newspaper El Pais is dedicated to the results of the ruling Popular party session that ended up with a motto «Either the Popular party or nothing». The author of the article ironically compares the Popular party with the «Kingdom of God» (el reino de los Cielos), which is opposed by the «outer darkness» that implies a person existing without God, for «God is Light» (1 John 1:5). The same is proved in the following author's reference to one of the main Roman Catholic Church's postulates fuera de la Iglesia no hay salvación - Extra Ecclesiam nulla salus (Latin «Outside the Church there is no salvation»).

Semantic transformations of the biblical expressions: literalization

In the process of literalization the direct meaning of the idiom dominates, which is the basis for its figurativeness. The original meaning of a phrase is more often juxtaposed to its idiomatic meaning.

The article about a tragic destiny of the beauty contest winner Miss, una corona de espinas en Latinoamérica bears in its title a biblical expression corona de espinas (crown of thorns), a symbol of suffer, grief, and severe ordeals. Thus literalization is realized: the Queen of beauty's crown appears to be a crown of thorns for the girl.

To conclude, the use of idioms is one of the most expressive means in the Spanish media discourse. The author's biblical expressions are an integral part of the context, which allows the journalists to evaluate a certain event or phenomenon that happen in the modern world, and thus making the text more emphatic, emotive and expressive, or, on the other hand, more vivid, laconic, and simple.

\section{References:}

1. Toporov, V. N. (1983). Space and Text. Text: Semantics and Structure, 227-284.

2. Kunin, A. V. (Ed.). (1996). A Course on Phraseology of the Modern English Language: a textbook ( $2^{\text {nd }}$ ed.). Moscow: Phoenix.

3. Zuluaga, Ospina A. (1997). On Functions of Phraseology in Literature. Paremia, 6, 631-640.

4. El Tiempo (2002, August 10). Retrieved from: http://www.eltiempo.com/archivo/documento/ MAMV1336389

5. Style of Life (2014, September 11). El confidencial. Retrieved from: http://www. estilo. elconfidencial. com/ estilo V de Vvida/2014V09V11/ vive V la V vendimia V $12 \mathrm{~V}$ planes V alrededor V del V vino_188589

6. Iskanderova, V. I. (2005). The Biblical Phraseology in the French Press Media. 5th Stepanov Readings. Language in the Modern World, 263-265.

7. The Bible on the Internet. Retrieved from: http://www.biblija.net/biblija.cgi?l=es 